\title{
Serological survey of SARS-CoV-2 incidence conducted at a rural West Virginia hospital
}

${ }^{1}$ Department of Microbiology, Immunology, and Cell Biology, West Virginia University, Morgantown, West

${ }^{2}$ Vaccine Development Center at West Virginia University Health Sciences Center, Morgantown, West Virginia,

${ }^{3}$ West Virginia University Clinical and Translational Science Institute, Morgantown, West Virginia, USA.

${ }^{4}$ Montgomery General Hospital, Montgomery, West Virginia, USA.

${ }^{5}$ Fayette County Health Department, Fayetteville, West Virginia, USA.

${ }^{6}$ Department of Pediatrics, West Virginia University School of Medicine, Morgantown, West Virginia, USA.

${ }^{7}$ Department of Pathology, Anatomy and Laboratory Medicine, West Virginia University School of Medicine,

*A.M.H and B.P.R contributed equally to this study

${ }^{* *}$ denotes corresponding author

Corresponding author email: fdamron@hsc.wvu.edu

ABSTRACT: The SARS-CoV-2 pandemic has affected all types of global communities. Differences in urban and rural environments have led to varying levels of transmission within these subsets of the population. To fully understand the prevalence and impact of SARS-CoV-2 it is critical to survey both types of community. This study establishes the prevalence of SARS-CoV-2 in a rural community: Montgomery, West Virginia. Approximately $10 \%$ of participants exhibited serological or PCR-based results indicating exposure to SARS-CoV-2 within 6 months of the sampling date. Quantitative analysis of IgG levels against SARS-CoV-2 receptor binding domain (RBD) was used to stratify individuals based on antibody response to SARS-CoV-2. A significant negative correlation between date of exposure and degree of anti-SARS-CoV-2 RBD IgG $\left(R^{2}=0.9006\right)$ was discovered in addition to a correlation between neutralizing anti-SARS-CoV-2 antibodies $\left(R^{2}=0.8880\right)$ and days post exposure. Participants were confirmed to have normal immunogenic profiles by determining serum reactivity $B$. pertussis antigens commonly used in standardized vaccines. No significant associations were determined between anti-SARS-CoV-2 RBD IgG and age or biological sex. Reporting of viral-like illness symptoms was similar in SARS-CoV-2 exposed participants greater than 30 years old (100\% reporting symptoms $30-60$ years old, $75 \%$ reporting symptoms $>60$ years old) in contrast to participants under 30 years old (25\% reporting symptoms). Overall, this analysis of a rural population provides important information about the SARS-CoV-2 pandemic in small rural communities. The study also underscores the fact that prior infection with SARS-CoV-2 results in antibody responses that wane over time which highlights the need for vaccine mediated protection in the absence of lasting protection. 
medRxiv preprint doi: https://doi.org/10.1101/2021.08.16.21262128; this version posted August 18, 2021. The copyright holder for this preprint (which was not certified by peer review) is the author/funder, who has granted medRxiv a license to display the preprint in perpetuity.

All rights reserved. No reuse allowed without permission.

INTRODUCTION: SARS-CoV-2 and the COVID-19 pandemic has dramatically impacted public health across the globe. In the early phase of the pandemic, SARS-CoV-2 rapidly infected urban centers in California, New York, and other major U.S. cities while infecting rural communities at reduced rates (Anand et al., 2020; Bajema et al., 2020; Duca et al., 2020; Menachemi et al., 2020). High infection rates in urban areas continued until July of 2020 at which point relative incidence began to decline. In September of 2020, SARSCoV-2 prevalence surged, this time including rural communities (Bajema et al., 2020; Duca et al., 2020). West Virginia was one of the last remaining states to report an active SARS-CoV-2 infection. This was likely due to a combination of early preventative measures and its highly rural population in contrast to some major urban locations. However, several states, including West Virginia, were dramatically impacted by the second surge after September 2020 and may have unique SARS-CoV-2 infection dynamics (Anand et al., 2020). As such, it is important to understand the impact of SARSCoV-2 in these populations.

Rural communities comprise approximately $95 \%$ of the land mass of the United States but only $19.3 \%$ of the total population (Health Resources \& Services Administration, 2021). Population densities in these areas are vastly different than major urban centers, often having an average of 45 times fewer people per square mile than major urban centers (Cohen, 2015). The impact on these communities during infectious disease outbreaks has been discussed for years. Specifically, rural communities have considerably different epidemic transmission concerns. Geographically disperse populations result in greater journeys to medical facilities or testing sites than urban citizens (Katz et al., 2020; Pritchard, 1935; Rader et al., 2020; Scoglio et al., 2010). In 
61 addition, rural populations have significantly different incidences of comorbidities

62 including diabetes, obesity, and respiratory conditions that may impact susceptibility

63 during infectious disease outbreaks (Garcia et al., 2017). Ultimately, these factors are

64 associated with significantly different rates of complications from infectious disease

65 outbreaks at the county level over the past 40 years (El Bcheraoui et al., 2018).

67 COVID-19, and frequency of SARS-CoV-2 in rural areas. The goal of this research was

to assess the frequency and characteristics of SARS-CoV-2 infection in a rural population.

69 This study sampled 150 participants from Montgomery, WV a rural community with a population of 1,592 individuals in 2019. Serological analyses of SARS-CoV-2 exposure

71 were conducted to understand binding antibody levels, neutralizing antibody levels and

72 demographic infection distributions in this rural West Virginia populace. With the

73 knowledge that rural states like West Virginia exhibited different rates of SARS-CoV-2

74 infection throughout the pandemic, and that these areas have high incidences of

75 comorbidities, we aimed to better understand the serological hallmarks of SARS-CoV-2 76 exposure in rural citizens.

\section{METHODS:}

79 Participant enrollment: Study recruitment was conducted on September 10, 2020 at

80 Montgomery General Hospital. After reviewing the informed consent document with any

81 questions answered by onsite study personnel, those desiring to participate in the study

82 signed the informed consent document. Medical records of consenting patients were 83 obtained in addition to self-reported age, biological sex, ethnicity, race, medication list, 
medRxiv preprint doi: https://doi.org/10.1101/2021.08.16.21262128; this version posted August 18, 2021. The copyright holder for this preprint (which was not certified by peer review) is the author/funder, who has granted medRxiv a license to display the preprint in perpetuity.

All rights reserved. No reuse allowed without permission.

SARS-CoV-2 test dates (non-specified as PCR or antigen tests) with results, and whether they had experienced any viral-like illness symptoms throughout the time period of the pandemic. Consenting patients were then admitted to a separate room for venipuncture. This study was completed and overseen by the provisions of WVU IRB\#: 2008077079.

Serum sampling of study participants: Approximately $10 \mathrm{ml}$ of blood was obtained from consented patients via venipuncture, performed by licensed medical staff. Blood was collected into Tiger-top blood tubes, and specimens were centrifugated at 3500rpm for 15 minutes (Hettich Rotina-380) and then transported on dry ice to the WVU Vaccine Development center. Serum was aliquoted from the blood collection tubes into barcoded $13 \mathrm{~mm}$ sample tubes and frozen at $-80^{\circ} \mathrm{C}$ until use.

Quantitative analysis of anti-SARS-CoV-2 IgG production: Anti-SARS-CoV-2 RBD IgG levels were determined by automated ELISA using the Tecan Freedom EVO 150/200 series. All samples were screened for anti-SARS-CoV-2 activity by diluting $40 \mu \mathrm{L}$ of serum samples into $160 \mu \mathrm{L}$ of $1 \%$ non-fat milk dissolved in Phosphate Buffered Saline (PBS) + 0.1\% Tween 20 in a non-binding 96-well plate by a Tecan Freedom EVO 150. Diluted specimens were further serially diluted (5-fold) down the columns of the plate by the Tecan Freedom EVO 150. Samples $(100 \mu \mathrm{L})$ were transferred to a 96-well high-binding plate (Pierce Part \#:15041) coated with SARS-CoV-2 RBD $(2 \mu \mathrm{g} / \mathrm{mL}$ produced as previously described(Horspool et al., 2021)) and blocked with 3\% milk diluted in PBS $+0.1 \%$ Tween 20 as described previously(Horspool et al., 2021) by a Tecan Freedom EVO 200. Plates were incubated at room temperature shaking at $60 \mathrm{rpm}$ for $10 \mathrm{~min}$. After 
medRxiv preprint doi: https://doi.org/10.1101/2021.08.16.21262128; this version posted August 18, 2021. The copyright holder for this preprint (which was not certified by peer review) is the author/funder, who has granted medRxiv a license to display the preprint in perpetuity.

All rights reserved. No reuse allowed without permission.

107 incubating, plates were washed four times with $200 \mathrm{uL}$ of PBS $+0.1 \%$ Tween 20 by a

108 Tecan HydroSpeed attached to the Tecan Freedom EVO 200. Secondary antibody

$109(100 \mu \mathrm{L}$ of 1:500 goat-anti-human IgG HRP Invitrogen Part \#: 31410) was then added to each well. Plates were incubated at room temperature shaking at 60rpm for 10min. After

111 incubation, plates were washed five times with $200 \mathrm{uL}$ of PBS $+0.1 \%$ Tween 20 by a

112 Tecan HydroSpeed attached to the Tecan EVO 200. After washing, TMB (100 $\mu \mathrm{L}$ of 1:1

113 reagent $A$ : reagent $B$, Biolegend Part \#: 421101) was added to the each well of the plate.

114 Plates were incubated at room temperature for 10 min without shaking in the dark. Stop 115 solution ( $25 \mu \mathrm{L}$ of $3 \mathrm{M}$ hydrochloric acid) was added to stop the reaction. Plates were then

116 read by a Sunrise plate-reader and absorbance in each well was measured at a 117 wavelength of 450nm. Data analysis was completed in GraphPad Prism 9. Samples were 118 run simultaneously on the Abbott Architect system as a commercial qualitative 119 comparison of serological results.

121 Culture of B. pertussis for ELISA: B. pertussis (UT25) was struck on Bordet Gengou agar 122 (Remel (RM $^{\mathrm{TM}}$ 45232) supplemented with 15\% defibrinated sheep blood (Hemostat 123 Laboratories) and incubated for 2 days at $37^{\circ} \mathrm{C}$. After two days, bacteria from plates were 124 swabbed using polyester swabs (Fisher Scientific 22-029-574) into complete Stainer125 Scholte Medium (SSM) in new $125 \mathrm{~mL}$ flasks. Cultures were incubated at $37^{\circ} \mathrm{C}$ for 24 126 hours shaking at 180rpm. After incubation, B. pertussis cultures were diluted to an OD600 $127=0.24$ and used to coat ELISA plates. 
medRxiv preprint doi: https://doi.org/10.1101/2021.08.16.21262128; this version posted August 18, 2021. The copyright holder for this preprint (which was not certified by peer review) is the author/funder, who has granted medRxiv a license to display the preprint in perpetuity.

All rights reserved. No reuse allowed without permission.

129 Analysis of anti-B. pertussis and anti-Pertussis toxin IgG levels: High binding ELISA 130 plates (Pierce 15041) were coated with $B$. pertussis $(50 \mu \mathrm{L}$ of $\mathrm{OD}=0.24$ B. pertussis in

131 Stainer-Scholte Medium) or Pertussis toxin (List Labs \#180 at $1 \mu \mathrm{g} / \mathrm{mL}$ ). Plates were 132 incubated overnight at $4^{\circ} \mathrm{C}$. Plates were washed 3 times with $200 \mu \mathrm{L}$ of $\mathrm{PBS}+0.1 \%$ Tween 13320 . Blocking buffer $(200 \mu \mathrm{L}$ of $5 \%$ non-fat milk) was added to each well and plates were 134 incubated for $1 \mathrm{hr}$ at $37^{\circ} \mathrm{C}$. Plates were washed 3 times with $200 \mu \mathrm{L}$ of PBS $+0.1 \%$ Tween 135 20. Serum samples $(25 \mu \mathrm{L})$ from participants were added into $1 \%$ non-fat milk dissolved 136 in PBS $+0.1 \%$ Tween 20 in the first row of the plate. Samples were serially diluted (5-fold 137 dilution) down the plate to row G. Row $\mathrm{H}$ contained PBS as a negative control. Plates were incubated for $2 \mathrm{hrs}$ at $37^{\circ} \mathrm{C}$. Plates were washed 4 times with $200 \mu \mathrm{L}$ of PBS $+0.1 \%$

139 Tween 20. Secondary antibody $(100 \mu \mathrm{L}$ of 1:500 goat-anti-human IgG HRP Invitrogen Part \#: 31410) was then added to each well. Plates were incubated for $1 \mathrm{hr}$ at $37^{\circ} \mathrm{C}$. After

141 incubation, plates were washed five times with $200 \mathrm{uL}$ of PBS $+0.1 \%$ Tween 20 . TMB $142(100 \mu \mathrm{L})$ was added to the each well of the plate. Plates were incubated at room 143 temperature for $30 \mathrm{~min}$ in the dark. Stop solution $(25 \mu \mathrm{L}$ of $3 \mathrm{M}$ hydrochloric acid) was 144 added to stop the reaction. Plates were then read by a Sunrise plate-reader and 145 absorbance in each well was measured at a wavelength of $450 \mathrm{~nm}$.

147 Quantification of neutralizing antibodies: An assay to assess neutralizing antibody (nAb) 148 levels was developed using Luminex bead and Magpix technologies. SARS-CoV-2 RBD 149 (1 $\mu \mathrm{g})$ produced at WVU as described previously(Horspool et al., 2021) was conjugated 150 to Luminex MagPlex® Micospheres (MC10012-YY) using the Luminex xMAP antibody 151 coupling kit (Luminex 40-50016) per the manufacturer's instructions. Conjugated beads 
medRxiv preprint doi: https://doi.org/10.1101/2021.08.16.21262128; this version posted August 18, 2021. The copyright holder for this preprint (which was not certified by peer review) is the author/funder, who has granted medRxiv a license to display the preprint in perpetuity.

All rights reserved. No reuse allowed without permission.

152 (50 $\mathrm{LL}$ containing 2000 beads suspended in 1x PBS-TBN diluted from 5x PBS-TBN

153 Teknova \#:P0211) were loaded into black non-binding Greiner 96-well plates (Greiner

154 655900). Serum samples $25 \mu \mathrm{L}$ form participants were added into $100 \mu \mathrm{L}$ of PBS in the

155 first row of a second black non-binding plate. Samples were serially diluted (5-fold

156 dilution) down the plate to row G. Row $\mathrm{H}$ contained PBS as a negative control. Diluted

157 serum samples $(50 \mu \mathrm{L})$ were added to the 96 -well plate containing the beads, creating a

158 total reaction volume of $50 \mu \mathrm{L}$ beads (2000 beads), $50 \mu \mathrm{L}$ diluted serum. The plates were

159 covered with foil and shaken at 700rpm for $1 \mathrm{hr}$ at room temperature. After shaking, beads

160 were pelleted on a 96-well plate magnet and washed two times for two minutes with

$161200 \mu \mathrm{L}$ of $1 \times$ PBS-TBN. Beads were pelleted on the magnet and the wash solution

162 removed. ACE-2-biotin $(100 \mu \mathrm{L}$ at $0.25 \mu \mathrm{g} / \mathrm{mL}$, Sino Biological Inc \#: 10108-H08H-B) was

163 added to each well. Plates were covered with foil and shaken at 700rpm for $1 \mathrm{hr}$ at room

164 temperature. After shaking, beads were pelleted on a 96-well plate magnet and washed 165 two times for two minutes with $200 \mu \mathrm{L}$ of $1 \times$ PBS-TBN. Beads were pelleted on the magnet

166 and the wash solution removed. Streptavidin-phycoerythrin (MOSS INC: SAPE-001)

$167(100 \mu \mathrm{L}$ at $4 \mu \mathrm{g} / \mathrm{mL})$ was added to each well. Plates were covered with foil and shaken at

$168700 \mathrm{rpm}$ for $30 \mathrm{~min}$ at room temperature. After shaking, beads were pelleted on a 96-well

169 plate magnet and washed two times for two minutes with $200 \mu \mathrm{L}$ of $1 \times$ PBS-TBN. Beads

170 were resuspended in $100 \mu \mathrm{L}$ of $1 \times$ PBS-TBN and analyzed on a Luminex Magpix. Median

171 fluorescent intensity values were plotted against serum dilution factor, and a sigmoidal

172 regression line was fitted to the data using GraphPad Prism. Calculated IC50 values of

173 the sigmoidal curves were plotted separately as a measure of neutralizing capacity. 
medRxiv preprint doi: https://doi.org/10.1101/2021.08.16.21262128; this version posted August 18, 2021. The copyright holder for this preprint (which was not certified by peer review) is the author/funder, who has granted medRxiv a license to display the preprint in perpetuity.

All rights reserved. No reuse allowed without permission.

175 Statistical analyses: Statistical analyses were conducted using GraphPad Prism (version

9.0.0). Analyses of data linearity were completed by using the linear regression function

177 in GraphPad Prism. Correlations within datasets were investigated using two-tailed

178 Pearson correlation analyses. To assess statistical differences between two groups, a

179 two-tailed Student $t$-tests was used, or a one-way ANOVA followed by Tukey's multiple

180 comparison test to assess differences between multiple groups. Statistical significance

181 was determined to be $P<0.05$.

182

183

RESULTS:

184

Montgomery, West Virginia anti-SARS-CoV-2 RBD IgG levels: One hundred fifty

185 individuals consented to participate in the study, and venipuncture was performed to 186 assess prior exposure to SARS-CoV-2. The mean participant age was 48 years (S.D. = 187 +/- 15 years) and was comprised of $30 \%$ biological males (Table 1). SARS-CoV-2 188 incidence was determined to be $10 \%$ (15/150 participants) (Table 1) by combining 189 information from serological testing, patient reporting, and prior PCR based SARS-CoV1902 test results obtained from medical records. Quantitative serological testing for anti191 SARS-CoV-2 RBD IgG was completed at the WVU Vaccine Development center utilizing 192 methodology and cutoff values previously described(Horspool et al., 2021). The WVU 193 VDC antibody analyses identified $87 \%$ (13/15) of individuals with medical history of 194 SARS-CoV-2 exposure within six months of this study (Table 1). A similar commercial 195 qualitative SARS-CoV-2 IgG testing method (Abbott) identified 67\% (10/15) exposed 196 individuals. 
medRxiv preprint doi: https://doi.org/10.1101/2021.08.16.21262128; this version posted August 18, 2021. The copyright holder for this preprint (which was not certified by peer review) is the author/funder, who has granted medRxiv a license to display the preprint in perpetuity. All rights reserved. No reuse allowed without permission.

Anti-SARS-CoV-2 lgG levels decrease post-exposure: Serum from participants was diluted on direct-ELISA plates to determine semi-quantitative values of anti-SARS-CoV2 RBD IgG production. Absorbances of diluted patient samples and a comparison of area under the curve analysis described previously(Horspool et al., 2021) demonstrate clear differences between SARS-CoV-2 exposed and non-exposed participants (Figure 1A-B). Among those previously infected with SARS-CoV-2, neither age nor sex were associated with timing of infection (Supplementary Figure 1). To understand the impact of time on anti-SARS-CoV-2 RBD IgG levels, anti-RBD AUC values of exposed individuals were correlated against time post-SARS-CoV-2 exposure (Figure 1C). There is a significant inverse correlation between quantity of anti-SARS-CoV-2 RBD IgG and days postinfection, and individuals who were admitted to the hospital during infection had higher anti-RBD IgG levels. Data of anti-SARS-CoV-2 IgG levels over time were compared to a previous study of acute SARS-CoV-2 IgG levels in a West Virginian hospital(Horspool et al., 2021). Irrespective of hospitalization, individuals infected with SARS-CoV-2 within 3 months of diagnosis produced similar quantities of anti-SARS-CoV-2 RBD levels (Figure 1D). These levels significantly decreased over subsequent months post-exposure.

\section{Study participants possess normal immunogenic profiles against B. pertussis:} Immunocompromised individuals can lack appropriate responses to infectious diseases and vaccines. These individuals may bias results in a serological study. To understand whether the SARS-CoV-2 exposed participants from this study possessed abnormal immunogenic profiles, we assessed antibody production to an additional pathogen most people are vaccinated against: $B$. pertussis. Serum from SARS-CoV-2 exposed and a 
medRxiv preprint doi: https://doi.org/10.1101/2021.08.16.21262128; this version posted August 18, 2021. The copyright holder for this preprint (which was not certified by peer review) is the author/funder, who has granted medRxiv a license to display the preprint in perpetuity.

All rights reserved. No reuse allowed without permission.

221 selection of non-exposed individuals were tested for lgG production against whole $B$.

222 pertussis and Pertussis toxin. The data indicate that there was no difference in anti-B.

223 pertussis (Figure 2A-B) or anti-Pertussis toxin (Figure 2C-D) IgG levels between

224 individuals exposed or not exposed to SARS-CoV-2. These data suggest that there is a

225 similar immunogenic profile between each cohort and can assume this study was mostly

226 comprised of immunocompetent subjects.

227

228

Neutralizing antibodies against SARS-CoV-2 decrease post-exposure: Antibodies that

229 neutralize the capacity of SARS-CoV-2 RBD to bind to the human ACE-2 receptor were evaluated from participant serum. Neutralizing antibodies (nAbs) blocking an interaction between immobilized RBD and soluble ACE-2 with a fluorescently labeled epitope were

232 quantified by a modified Luminex assay. Neutralization curves and IC50 values of 233 participant serum indicate that approximately 53\% (8/15) of SARS-CoV-2 exposed 234 individuals have nAbs that are sufficient to block the RBD-ACE-2 interaction in vitro. nAb 235 quantities were further investigated by correlating nAb IC50s to time post-SARS-CoV-2 exposure. IC50 values appear to decrease significantly over five months post-exposure 237 (Figure 3C) particularly in individuals greater than 3 months post-exposure (Figure 3D).

240 IgG levels of SARS-CoV-2 of non-hospitalized individuals greater than 3 months post- 
medRxiv preprint doi: https://doi.org/10.1101/2021.08.16.21262128; this version posted August 18, 2021. The copyright holder for this preprint (which was not certified by peer review) is the author/funder, who has granted medRxiv a license to display the preprint in perpetuity.

All rights reserved. No reuse allowed without permission.

244 that were hospitalized had significantly higher levels of IgG and introduced bias un-related

245 to the demographic being evaluated. However, there was a noticeable difference in

246 reporting of viral-like symptoms between exposed individuals when compartmentalized

247 by age (Figures 4C-E). Participants under 30 years old (Figure 4C) reported viral-like

248 symptoms at a lower frequency than individuals greater than 30 years old (Figures 4D-

249 E).

250

251 DISCUSSION: Epidemics and pandemics impact rural and urban communities differently.

252 Community health, disease transmission dynamics, and resources vary in large cities vs

253 rural towns(Mueller et al., 2021; Schweda et al., 2021; Scoglio et al., 2010; Singh et al.,

254 2019). This study revealed that the incidence of SARS-CoV-2 in a subset of a rural West

255 Virginian population is approximately $10 \%$ which is high relative to the national average

256 for that time period(Johns Hopkins University of Medicine, 2021). It is possible that the

257 decreased number of community facilities including convenience stores, food services,

258 hospitals, etc. may have increased the proportion of the community contacted by an

259 infected person. In addition, rural communities are statistically more likely to have

260 residents with comorbidities including diabetes, obesity, and respiratory

261 conditions(Garcia et al., 2017). Increased incidence of comorbidities may impact the

262 likelihood of contracting COVID-19 in a rural setting, though larger controlled studies must

263 be completed to address this hypothesis.

The significant decreases observed in anti-SARS-CoV-2 IgG over time have been

266 Ward et al., 2020), but not in the context of rural communities. Declining anti-SARS-CoV- 
medRxiv preprint doi: https://doi.org/10.1101/2021.08.16.21262128; this version posted August 18, 2021. The copyright holder for this preprint (which was not certified by peer review) is the author/funder, who has granted medRxiv a license to display the preprint in perpetuity.

All rights reserved. No reuse allowed without permission.

2672 antibody levels is a cause for concern for individuals that have convalesced from 268 infection and warrants further investigation. The comparable trend of declining nAbs in 269 participants is particularly alarming as this indicates that this decline may not be limited 270 to IgGs but may encompass other classes of antibodies interfacing with SARS-CoV-2 271 RBD. Additional results have been produced by other studies internationally with variable 272 rates of decline (Choe et al., 2021; Long et al., 2020; Seow et al., 2020; Wang et al., 273 2020). Ultimately, these data may be critical in understanding the risks of declining anti274 SARS-CoV-2 immunity and the potential for SARS-CoV-2 reinfection in rural 275 communities. Further studies examining this effect in other areas in the United States will be imperative to better understand differences in urban-rural immunity as the pandemic 277 continues. CoV-2 IgG production (Chakravarty et al., 2020; Horspool et al., 2021; Robbiani et al., 2020; Scully et al., 2020; Takahashi et al., 2020; Zeng et al., 2020). In many of these studies, neither age, nor sex significantly impact anti-SARS-CoV-2 RBD IgG production, a result that is reflected in this study. However, the data presented here is limited in the number of positive cases identified due to a sampling of a small rural community. Despite 284 this finding, an interesting trend emerged in reports of viral-like symptoms from individuals exposed to SARS-CoV-2. The incidence of reported viral-like illness symptoms in 286 participants over the age of 30 years old indirectly suggests a more severe course of 287 COVID-19. It has been established that COVID-19 severity is increased with age (Cortis, 2020; Davies et al., 2020; Yuki et al., 2020). Indeed, three individuals in this study were hospitalized for COVID-19 all of whom were over the age of 30 and two of whom were 
medRxiv preprint doi: https://doi.org/10.1101/2021.08.16.21262128; this version posted August 18, 2021. The copyright holder for this preprint (which was not certified by peer review) is the author/funder, who has granted medRxiv a license to display the preprint in perpetuity.

All rights reserved. No reuse allowed without permission.

over the age of 60 . Although much larger studies have assessed these variables in urban populations, it is informative to note that similar conclusions may be applicable to this rural population.

Overall, this study provides a compact analysis of SARS-CoV-2 incidence conducted at a rural West Virginia hospital. Total incidence taken at this community hospital appears high relative to the national average at that time which may be due to different rural transmission networks. The levels of anti-SARS-CoV-2 RBD IgG and nAbs in participants appear to decrease over six months post-infection, and no participants appeared to have abnormal immunogenic profiles to a standard vaccine pathogen. The trends described in this work are independent of age and sex in concordance with other literature. Overall, the results of this study suggest decreasing immunity in rural persons which may negatively impact ability of a population to attain herd immunity without a vaccine that provides longer-lasting protection. This emphasizes the need for vaccine coverage among a large portion of the population. Ultimately, this study aids in understanding the manifestation of SARS-CoV-2 in rural populations which may be critical for combatting transmission in underserved communities and may better inform prevention and vaccination efforts.

ACKNOWLEDGEMENTS: This project was supported by the Vaccine Development Center at the West Virginia University Health Sciences Center. F.H.D. and the VDC are supported by the Research Challenge Grant no. HEPC.dsr.18.6 from the Division of Science and Research, WV Higher Education Policy Commission. Research reported in this publication was also supported by the National Institute of General Medical Sciences 
medRxiv preprint doi: https://doi.org/10.1101/2021.08.16.21262128; this version posted August 18, 2021. The copyright holder for this preprint (which was not certified by peer review) is the author/funder, who has granted medRxiv a license to display the preprint in perpetuity.

All rights reserved. No reuse allowed without permission.

313 of the National Institutes of Health under Award Number 5U54GM104942-05. The content

314 is solely the responsibility of the authors and does not necessarily represent the official

315 views of the National Institutes of Health.

316

317 AUTHOR CONTRIBUTIONS: AMH, RE, AS, LC, SW, TK, SH, FHD designed the study

318 and planned execution. RE, AS, LC, SW planned resource allocation and venipuncture

319 draws at Montgomery General hospital. MAW, JK, CBB, JH, TYW, MAD, GB, JRB

320 consented patients. AMH processed serum samples. AMH and BPR ran serological tests

321 including ELISAs and neutralization assays. BPR assisted in running ELISAs. All authors

322 contributed to writing and revision of the manuscript. 
REFERENCES:

325

326

327

328

329

330

331

332

Anand S, Montez-Rath M, Han J, Bozeman J, Kerschmann R, Beyer P, et al.

Prevalence of SARS-CoV-2 antibodies in a large nationwide sample of patients on dialysis in the USA: a cross-sectional study. Lancet 2020;396:1335-44. https://doi.org/10.1016/S0140-6736(20)32009-2.

Bajema KL, Wiegand RE, Cuffe K, Patel S V., Iachan R, Lim T, et al. Estimated SARSCoV-2 Seroprevalence in the US as of September 2020. JAMA Intern Med 2020;30329:1-11. https://doi.org/10.1001/jamainternmed.2020.7976.

El Bcheraoui C, Mokdad AH, Dwyer-Lindgren L, Bertozzi-Villa A, WStubbs R, Morozoff C, et al. Trends and patterns of differences in infectious disease mortality among US Counties, 1980-2014. JAMA - J Am Med Assoc 2018;319:1248-60. https://doi.org/10.1001/jama.2018.2089.

Chakravarty D, Nair SS, Hammouda N, Ratnani P, Gharib Y, Wagaskar V, et al. Sex differences in SARS-CoV-2 infection rates and the potential link to prostate cancer. Commun Biol 2020;3:1-12. https://doi.org/10.1038/s42003-020-1088-9. Choe PG, Kang CK, Suh HJ, Jung J, Song KH, Bang JH, et al. Waning antibody responses in asymptomatic and symptomatic SARS-CoV-2 infection. Emerg Infect Dis 2021;27:327-9. https://doi.org/10.3201/eid2701.203515.

Cohen D. Understanding Population Density. United States Census Bur 2015. https://www.census.gov/newsroom/blogs/random-samplings/2015/03/understandingpopulation-density.html.

Cortis D. On Determining the Age Distribution of COVID-19 Pandemic. Front Public Heal 2020;8:1-3. https://doi.org/10.3389/fpubh.2020.00202. 
medRxiv preprint doi: https://doi.org/10.1101/2021.08.16.21262128; this version posted August 18, 2021. The copyright holder for this preprint (which was not certified by peer review) is the author/funder, who has granted medRxiv a license to display the preprint in perpetuity. All rights reserved. No reuse allowed without permission.

347 Davies NG, Klepac P, Liu Y, Prem K, Jit M, Pearson CAB, et al. Age-dependent effects

348 in the transmission and control of COVID-19 epidemics. Nat Med 2020;26:1205-11.

349 https://doi.org/10.1038/s41591-020-0962-9.

350 Duca LM, Coyle J, McCabe C, McLean C. COVID-19 Stats. Morb Mortal Wkly Rep

$3512020 ; 69: 2020$.

352 Garcia MC, Faul M, Massetti G, Thomas CC, Hong Y, Bauer UE, et al. Reducing

353 Potentially Excess Deaths from the Five Leading Causes of Death in the Rural United

354 States. Morb Mortal Wkly Rep 2017;66.

355 Health Resources \& Services Administration. Defining Rural Population 2021.

356 https://www.hrsa.gov/rural-health/about-us/definition/index.html\#: :text=Under this

357 definition\%2C about 21 , is still classified as rural.

358 Horspool AM, Kieffer T, Russ BP, DeJong MA, Wolf MA, Karakiozis JM, et al. Interplay 359 of Antibody and Cytokine Production Reveals CXCL13 as a Potential Novel Biomarker 360 of Lethal SARS-CoV-2 Infection. MSphere 2021;6.

361 https://doi.org/10.1128/mSphere.01324-20.

362 Johns Hopkins University of Medicine. CUMULATIVE CASES 2021.

363 https://coronavirus.jhu.edu/data/cumulative-cases.

364 Katz J, Danger-Katz M, Quealy K. A Detailed Map of Who Is Wearing Masks in the U.S.

365 New York Times 2020.

366 Long QX, Liu BZ, Deng HJ, Wu GC, Deng K, Chen YK, et al. Antibody responses to

367 SARS-CoV-2 in patients with COVID-19. Nat Med 2020;26:845-8.

368 https://doi.org/10.1038/s41591-020-0897-1.

369 Marot S, Malet I, Leducq V, Zafilaza K, Sterlin D, Planas D, et al. Rapid decline of 
neutralizing antibodies against SARS-CoV-2 among infected healthcare workers. Nat Commun 2021;12:1-7. https://doi.org/10.1038/s41467-021-21111-9.

Menachemi N, Yiannoutsos CT, Dixon BE, Duszynski TJ, Fadel WF, Wools-Kaloustian KK, et al. Population Point Prevalence of SARS-CoV-2 Infection Based on a Statewide Random Sample — Indiana, April 25-29, 2020. MMWR Morb Mortal Wkly Rep 2020;69:960-4. https://doi.org/10.15585/mmwr.mm6929e1.

Mueller JT, Mcconnell K, Berne P, Pofahl K, Merdjanoff AA, Farrell J. Impacts of the COVID-19 pandemic on rural America 2021;118:1-6.

https://doi.org/10.1073/pnas.2019378118/-/DCSupplemental.Published.

Perreault J, Tremblay T, Fournier MJ, Drouin M, Beaudoin-Bussières G, Prévost J, et al. Waning of SARS-CoV-2 RBD antibodies in longitudinal convalescent plasma samples within 4 months after symptom onset. Blood 2020;136:2588-91.

https://doi.org/10.1182/BLOOD.2020008367.

Pritchard DEP. The Control of Infectious Disease in Rural Areas. J R Sanit Inst 1935;56:432-6.

Rader B, Astley CM, Sy KTL, Sewalk K, Hswen Y, Brownstein JS, et al. Geographic access to United States SARS-CoV-2 testing sites highlights healthcare disparities and may bias transmission estimates. J Travel Med 2020;27:1-4.

https://doi.org/10.1093/jtm/taaa076.

Robbiani DF, Gaebler C, Muecksch F, Lorenzi JCC, Wang Z, Cho A, et al. Convergent antibody responses to SARS-CoV-2 in convalescent individuals. Nature 2020. https://doi.org/10.1038/s41586-020-2456-9.

Schweda A, Weismüller B, Bäuerle A, Dörrie N, Musche V, Fink M, et al. Phenotyping 
medRxiv preprint doi: https://doi.org/10.1101/2021.08.16.21262128; this version posted August 18, 2021. The copyright holder for this preprint (which was not certified by peer review) is the author/funder, who has granted medRxiv a license to display the preprint in perpetuity.

All rights reserved. No reuse allowed without permission.

393 mental health: Age, community size, and depression differently modulate COVID-19-

394 related fear and generalized anxiety 2021;104.

395 https://doi.org/10.1016/j.comppsych.2020.152218.

396 Scoglio C, Schumm W, Schumm P, Easton T, Chowdhury SR, Sydney A, et al. Efficient

397 mitigation strategies for epidemics in rural regions. PLoS One 2010;5:1-8.

398 https://doi.org/10.1371/journal.pone.0011569.

399 Scully EP, Haverfield J, Ursin RL, Tannenbaum C, Klein SL. Considering how biological

400 sex impacts immune responses and COVID-19 outcomes. Nat Rev Immunol

401 2020;20:442-7. https://doi.org/10.1038/s41577-020-0348-8.

402 Self WH, Tenforde MW, Stubblefield WB, Feldstein LR, Steingrub JS, Shapiro NI, et al.

403 Decline in SARS-CoV-2 Antibodies After Mild Infection Among Frontline Health Care

404 Personnel in a Multistate Hospital Network - 12 States, April-August 2020. MMWR

405 Morb Mortal Wkly Rep 2020;69:1762-6. https://doi.org/10.15585/mmwr.mm6947a2.

406 Seow J, Graham C, Merrick B, Acors S, Pickering S, Steel KJA, et al. Longitudinal

407 observation and decline of neutralizing antibody responses in the three months

408 following SARS-CoV-2 infection in humans. Nat Microbiol 2020;5:1598-607.

409 https://doi.org/10.1038/s41564-020-00813-8.

410 Singh M, Sarkhel P, Kang GJ, Marathe A, Murray-tuite P, Abbas KM, et al. Impact of

411 demographic disparities in social distancing and vaccination on influenza epidemics in

412 urban and rural regions of the United States 2019:1-13.

413 Takahashi T, Wong P, Ellingson M, Lucas C, Klein J, Israelow B, et al. Sex differences

414 in immune responses to SARS-CoV-2 that underlie disease outcomes. MedRxiv

415 2020:2020.06.06.20123414. https://doi.org/10.1101/2020.06.06.20123414. 
416 Wang K, Long Q-X, Deng H-J, Hu J, Gao Q-Z, Zhang G-J, et al. Longitudinal Dynamics

417 of the Neutralizing Antibody Response to Severe Acute Respiratory Syndrome

418 Coronavirus 2 (SARS-CoV-2) Infection. Clin Infect Dis 2020;2.

419 https://doi.org/10.1093/cid/ciaa1143.

420 Ward H, Cooke G, Atchison C, Whitaker M, Elliott J, Moshe M, et al. Declining

421 prevalence of antibody positivity to SARS-CoV-2: a community study of 365,000 adults.

422 MedRxiv 2020.

423 Yuki K, Fujiogi M, Koutsogiannaki S. COVID-19 pathophysiology: A review. Clin

424 Immunol 2020;215. https://doi.org/10.1016/j.clim.2020.108427.

425 Zeng F, Dai C, Cai P, Wang J, Xu L, Li J, et al. A comparison study of SARS-CoV-2 IgG

426 antibody between male and female COVID-19 patients: a possible reason underlying

427 different outcome between gender. MedRxiv 2020:2020.03.26.20040709.

428 https://doi.org/10.1101/2020.03.26.20040709.

429

430

431

432

433

434

435

436

437 
440 Table 1| Study participant information: Average age, biological sex distribution, and

441 SARS-CoV-2 exposure were determined for the participants of this study. Proportion of 442 patients exposed or not exposed to SARS-CoV-2 and the WVU VDC detection rates of

443 known exposed individuals. $n=150$ participants.

\begin{tabular}{|l|c|c|c|}
\hline Demographics & Age & Proportion biologically male & SARS-CoV-2 +/- \\
\hline Average & $48 \mathrm{yrs}$ & $30 \%$ & $9 \%$ \\
\hline SD & $15 \mathrm{yrs}$ & N/A & N/A \\
\hline SARS-CoV-2 history & Positive & Negative & VDC Detected \\
\hline \# of total & $15 / 150$ & $135 / 150$ & $13 / 150$ \\
\hline$\%$ of total & 10 & 90 & 8.67 \\
\hline
\end{tabular}




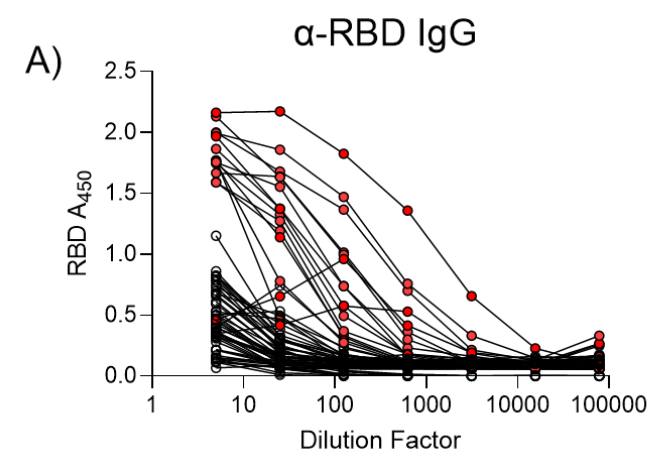

B)
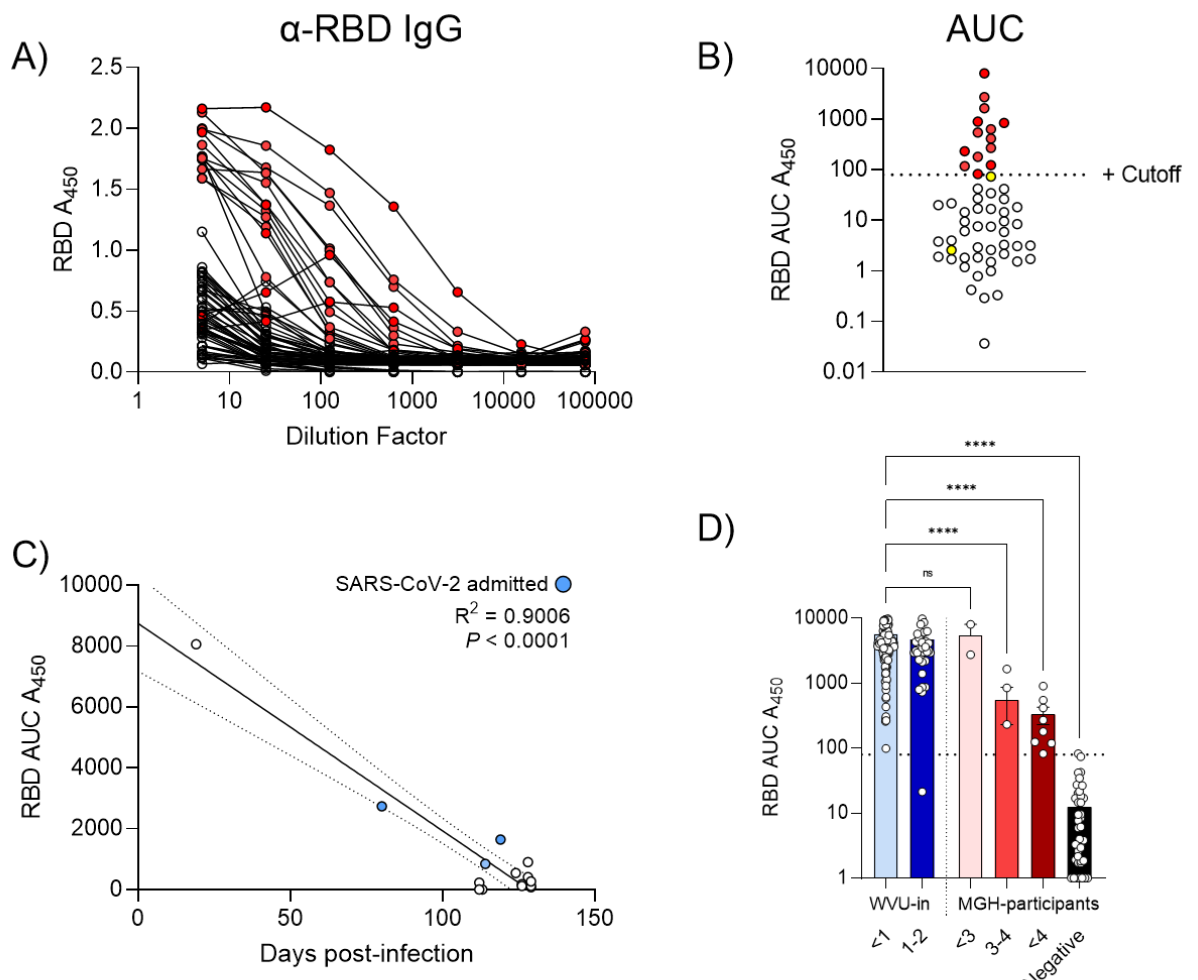

D)

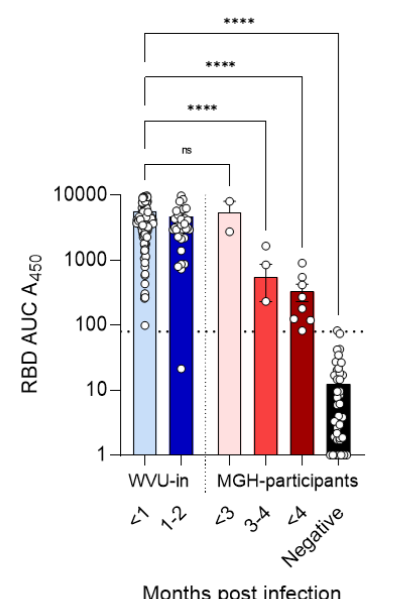

Figure 1 | Anti-SARS-CoV-2 IgG levels of study participants: Levels of anti-SARS-

SARS-CoV-2 ELISA plates. Red symbols = SARS-CoV-2 exposed, white symbols = nonanalysis of each patient curve plotted against previously defined cutoff values for SARSCoV-2 exposure ${ }^{13}$. C) Anti-SARS-CoV-2 RBD IgG levels of exposed participants were plotted against the number of days after the participant tested positive for SARS-CoV-2. Blue dots represent participants that were admitted to the hospital during infection. D)

468 Comparison of anti-RBD AUC values from a prior study and this study over time. 469 Statistical significance was assessed by a two-tailed Pearson correlation or a one-way 
ANOVA followed by a Tukey's multiple comparison test. ${ }^{* * * *}=P<0.0001$, ns $=$ not

471 significant.

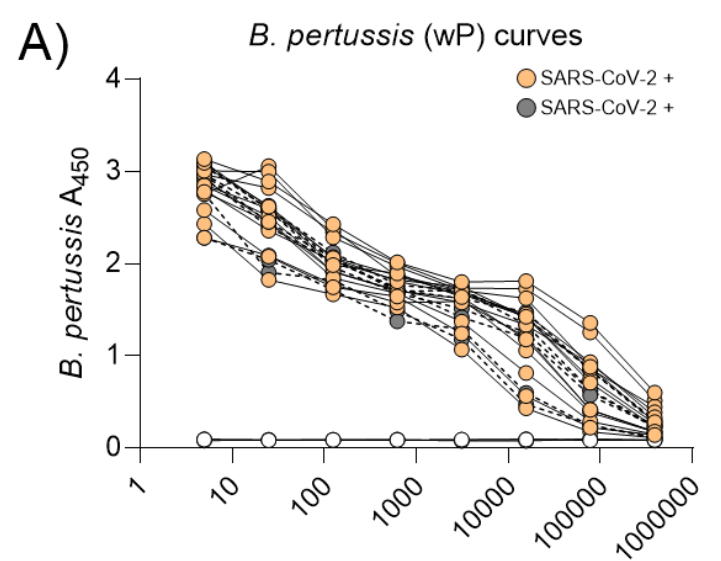

Dilution Factor

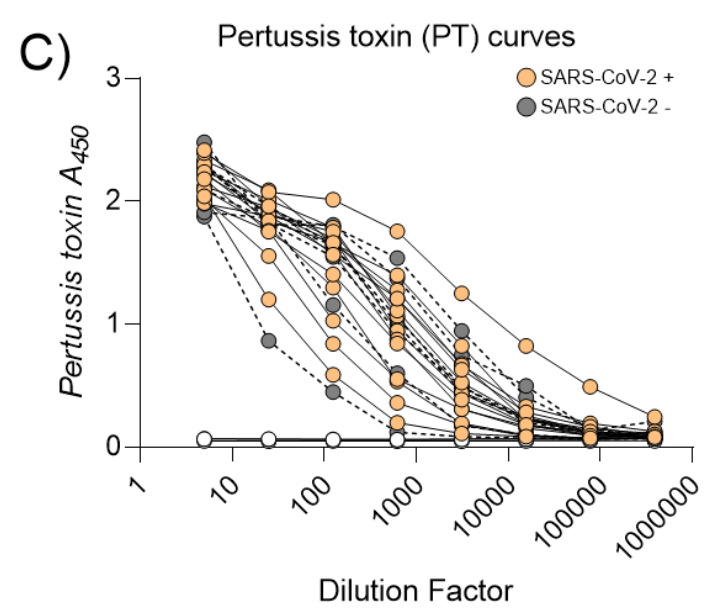

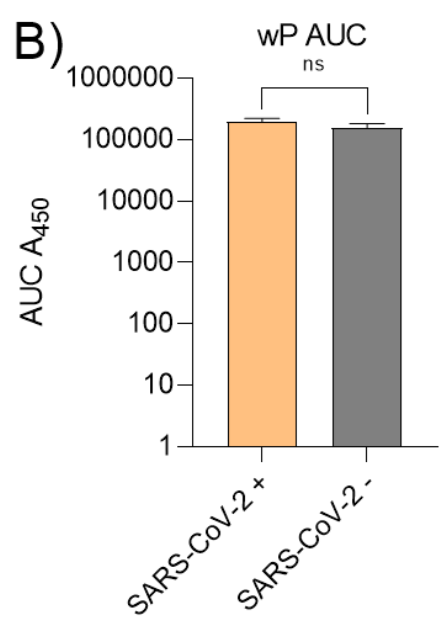

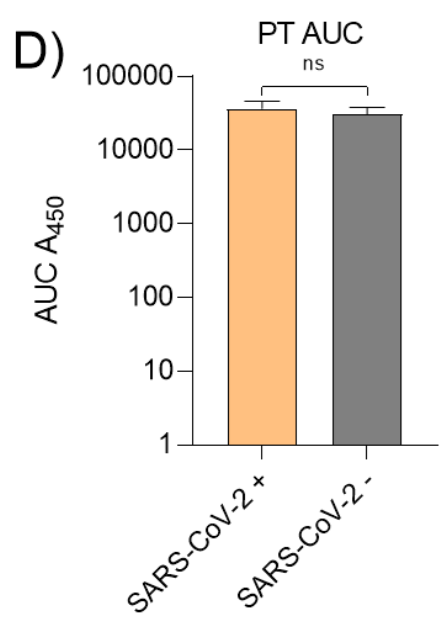

472

473 Figure 2 | Anti-B. pertussis and anti-Pertussis toxin Ig levels of study participants:

474 A) Titration of participant samples on $B$. pertussis ELISA plates. Orange symbols = SARS-

475 CoV-2 exposed, grey symbols $=$ non-exposed, white symbols $=$ negative control). B) Area

478 plates. Orange symbols $=$ SARS-CoV-2 exposed, grey symbols $=$ non-exposed, white 479 not exposed to SARS-CoV-2. C) Titration of participant samples on Pertussis toxin ELISA under the curve (AUC) analysis of $B$. pertussis ELISA curves of participants exposed or symbols $=$ negative control). D) Area under the curve (AUC) analysis of Pertussis toxin 

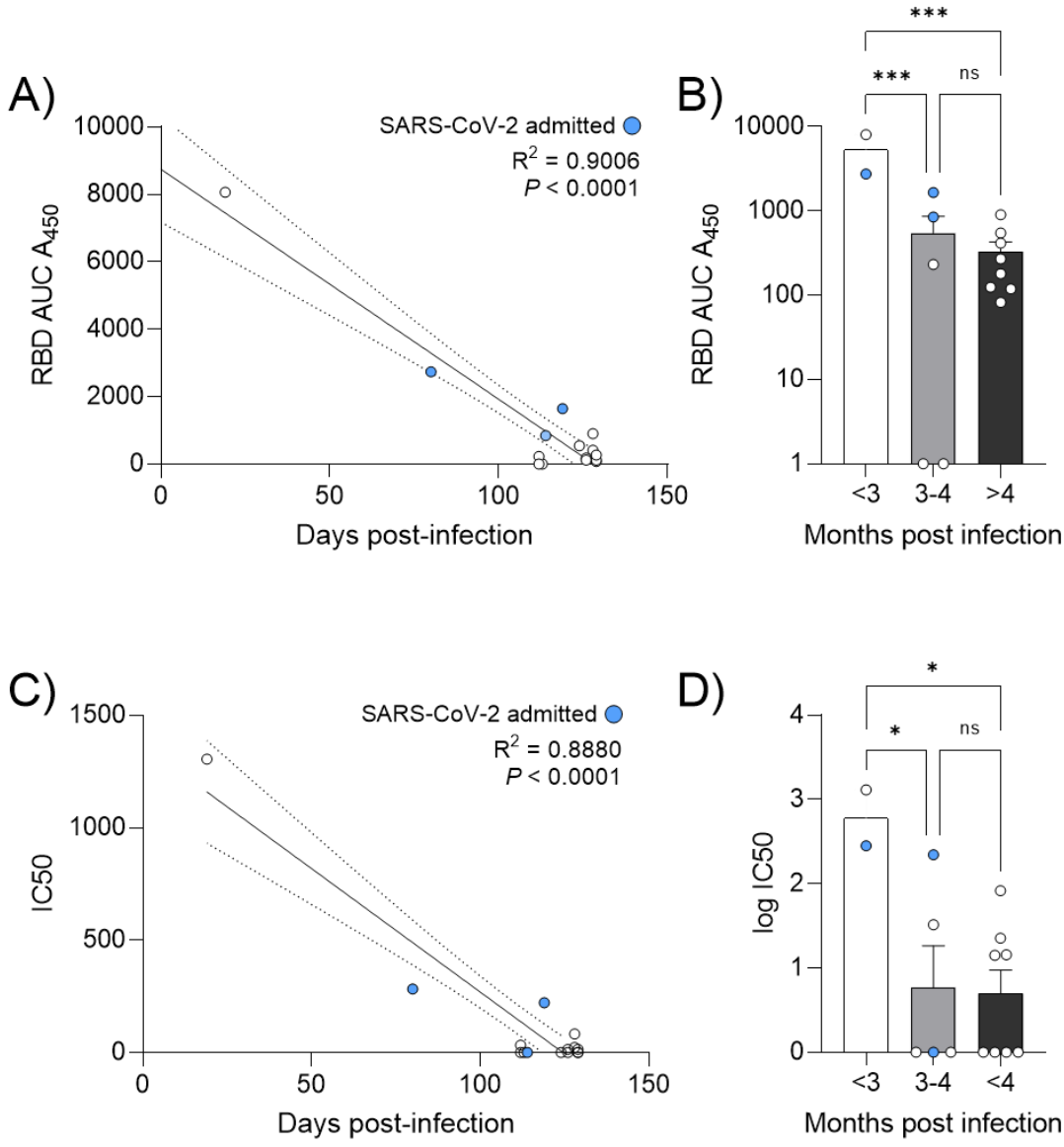

Figure 3 | Anti-SARS-CoV-2 IgG levels appear decreased over time: A) Anti-SARSCoV-2 nAb curves of study participants. B) Anti-SARS-CoV-2 nAb IC50 values at the time of this study were plotted and a cutoff between neutralizing and non-neutralizing samples was drawn. C) nAb levels of exposed participants were plotted against the number of 487 days after the participant tested positive for SARS-CoV-2. Blue dots represent 488 participants that were admitted to the hospital during infection. D) Comparison of nAb 489 IC50 values from this study over time. Linear regression was calculated in GraphPad 490 Prism 9. Statistical significance was assessed by a two-tailed Pearson correlation or a 
medRxiv preprint doi: https://doi.org/10.1101/2021.08.16.21262128; this version posted August 18, 2021. The copyright holder for this preprint (which was not certified by peer review) is the author/funder, who has granted medRxiv a license to display the preprint in perpetuity.

All rights reserved. No reuse allowed without permission.

491 one-way ANOVA followed by a Tukey's multiple comparison test. ${ }^{*}=P<0.05$, ns $=$ not 492 significant.
A)
Age
$P=\mathrm{ns}$
C)
0000000000
. 0000000000

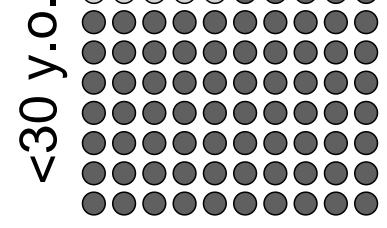

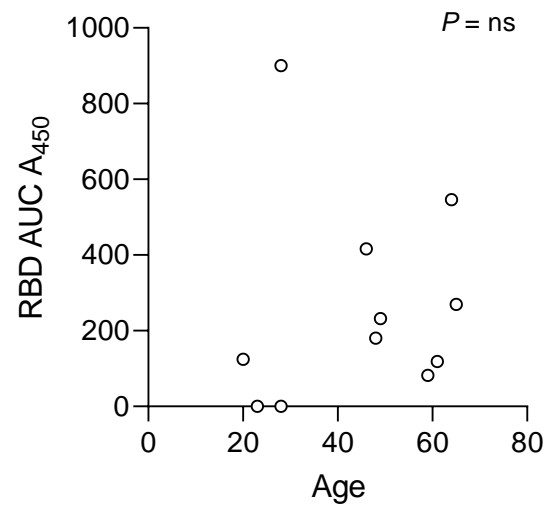
$\square 25.00 \%$ Reported viral-like illness
$75.00 \%$ Did not report viral-like illnes
B)
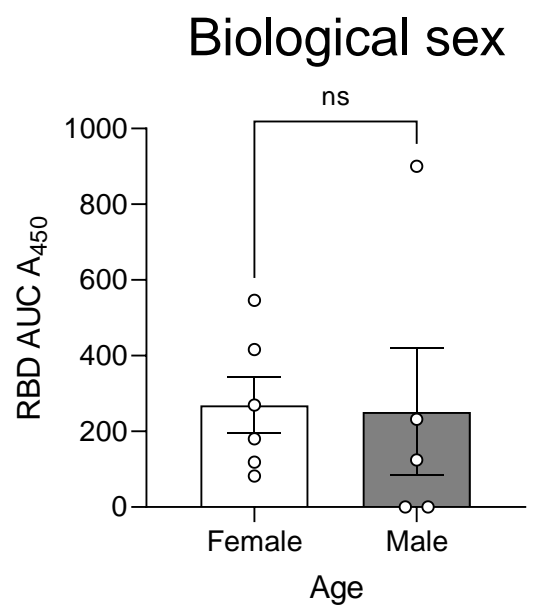 $\mathrm{n}=4$

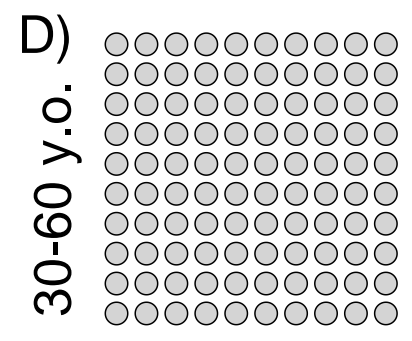
$\square 100.00 \%$ Reported viral-like illness
$\mathrm{n}=6$
E) $0000000000 \quad \square 75.00 \%$ Reported viral-like illness
$0000000000 \square 25.00 \%$ Did not report viral-like illnes

493

Figure 4 | Correlations between anti-SARS-CoV-2 IgG serological data and

questionnaire responses: A) Age and B) biological sex were plotted against anti-SARS-

CoV-2 exposed participants C) $<30$ years old, D) 30-60 years old, and E) $>60$ years old. 

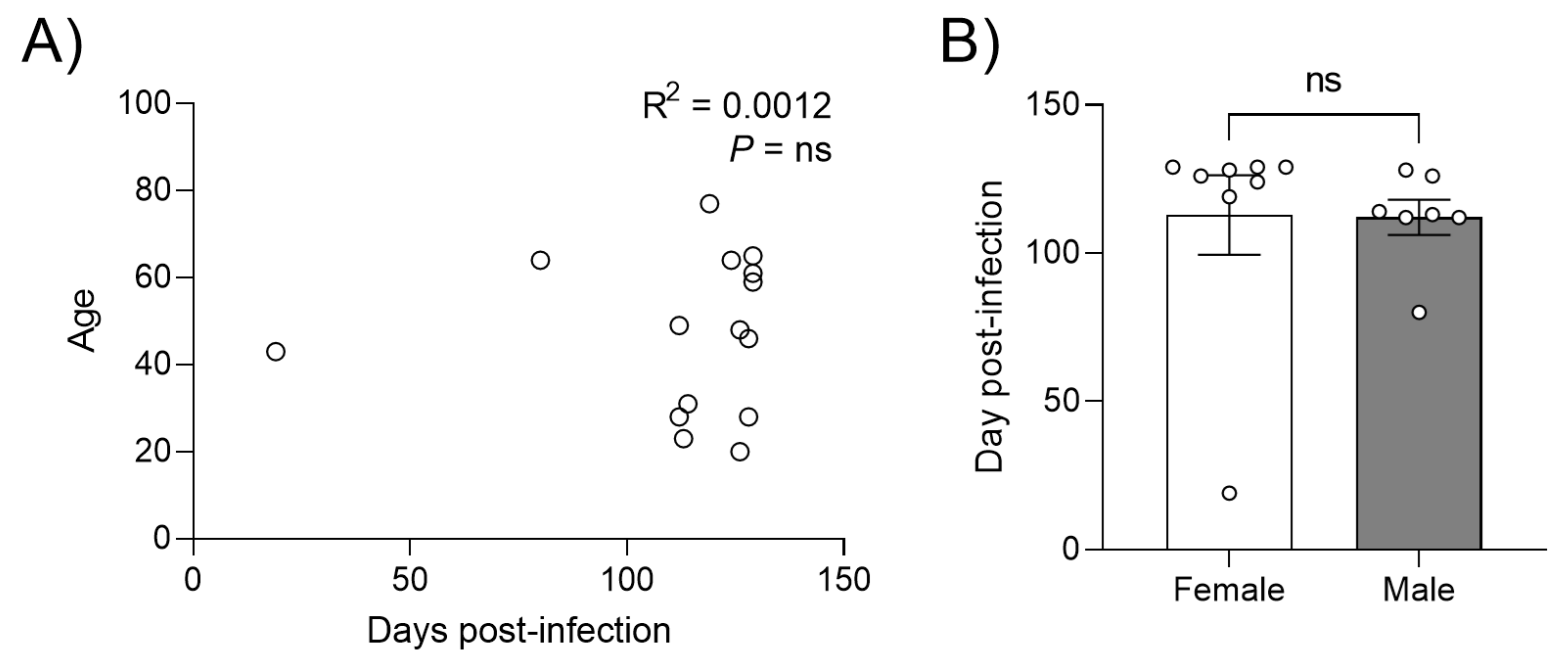
post-infection: A) Age correlated to days post-infection with SARS-CoV-2 and B) biological sex correlated to days post-infection. Statistical significance was assessed by 509 either two-tailed Pearson correlation or two-tailed student t-test. ns = not significant. 